\title{
ANTIBODIES TO THE ATHEROSCLEROTIC PLAQUE COMPONENTS BETA2-GLYCOPROTEIN I AND HEAT- SHOCK PROTEINS AS RISK FACTORS FOR ACUTE CEREBRAL ISCHEMIA
}

\author{
Henrique Luiz Staub1, Gary Lewis Norman², Tiffany Crowther², \\ Viviane Roseli da Cunha1, Aline Polanczyk1, Jussara Maria Bohn', \\ Jefferson Gomes Fernandes ${ }^{3}$, Wiliam Habib Chahade ${ }^{4}$, \\ Carlos Alberto von Mühlen ${ }^{1}$
}

\begin{abstract}
One third of cases of cerebral ischemia have no clear etiology. A humoral response to the atherosclerotic plaques components beta2-glycoprotein I (beta2-gpl) and heat-shock proteins (Hsp) might be involved in the pathogenesis of stroke. This case-control study includes a complete profile of anti-beta2-gpl antibodies and testing of IgG antibodies to the $60 / 65$ kilodaltons $(\mathrm{kDa}) \mathrm{Hsp}$ in stroke patients. Ninety-three patients with acute ischemic stroke and 93 controls were evaluated for age, sex, race, hypertension, smoking, previous cardiopathy, diabetes mellitus, hypercholesterolemia and previous history of cerebral ischemia. IgG/ $\operatorname{lgM} / \mathrm{lgA}$ anticardiolipin $(\mathrm{aCL})$ and anti-beta2-gpl antibodies, as well as IgG antibodies to human $60 \mathrm{kDa} \mathrm{Hsp}$ and to Mycobacterium bovis $65 \mathrm{kDa} \mathrm{Hsp}$, were detected by immunoassay. Adjusted odds ratios (OR) were calculated by logistic regression. The adjusted OR for IgA anti-beta2-gpl antibodies was $4.6(90 \% \mathrm{Cl} 1.5$ to 14.3; $p=0.025$ ). The non-adjusted OR for IgG antibodies to Hsp 60 was 26.1. The adjusted OR for $\lg G$ antibodies to $\mathrm{Hsp} 65$ was $3.2(90 \% \mathrm{Cl} 1.2$ to $8.3 ; \mathrm{p}=0.044)$. The adjusted OR for IgG to any $\mathrm{Hsp}(60$ or 65$)$ was $4.8(90 \% \mathrm{Cl} 1.9$ to $12.1 ; \mathrm{p}=0.006)$. This study demonstrates that elevated IgA anti-beta2-gpl and IgG antiHsp 60/65 antibodies are associated with increased risk of ischemic stroke. The association occurred independently of other risk factors. This humoral response might link autoimmunity, thrombophilia and atherosclerosis in stroke patients.
\end{abstract}

KEY WORDS: anti-beta2-gpl antibodies, anti-Hsp 60/65 antibodies, acute cerebral ischemia.

\begin{abstract}
Anticorpos contra os componentes da placa aterosclerótica beta2-glicoproteína I e proteínas de choque térmico como fatores de risco para isquemia cerebral aguda
\end{abstract}

RESUMO - Um terço dos casos de isquemia cerebral não apresenta etiologia clara. Uma resposta humoral contra os componentes da placa aterosclerótica beta2-glicoproteína I (beta2-gpl) e proteínas de choque térmico ("heat-shock proteins", Hsp) pode estar envolvida na patogênese do infarto cerebral. Este estudo de caso-controles inclui um perfil completo de anticorpos anti-beta2-gpl e a testagem de lgG anti-Hsp de 60/65 kilodaltons $(\mathrm{kDa})$ em pacientes com isquemia cerebral. Noventa e três pacientes com isquemia cerebral aguda e 93 controles foram avaliados quanto a idade, sexo, raça, hipertensão arterial, tabagismo, cardiopatia prévia, diabete mellitus, hipercolesterolemia e história prévia de isquemia cerebral. $\lg \mathrm{G} / \mathrm{lgM} / \mathrm{lgA}$ anticardiolipina (aCL) e anti-beta2-gpl, assim como lgG contra Hsp humana de 60 kDa e Hsp de Mycobacterium bovis de 65 kDa foram detectados por imunoensaio. Odds ratios (OR) ajustados foram calculados através de regressão logística. O OR ajustado para anticorpos IgA anti-beta2-gpl foi 4,6 (IC90\% 1,5 a 14,3 p =0,025). O OR não-ajustado para anticorpos IgG contra Hsp 60 foi 26,1 . O OR ajustado para anticorpos IgG contra Hsp 65 foi 3,2 (IC90\% $1,2$ a 8,3; $p=0,044)$. O OR ajustado para IgG contra qualquer Hsp (60 ou 65) foi 4,8 (IC90\% 1,9 a 12,1; $p=$ 0,006). $O$ estudo demonstra que níveis elevados de anticorpos IgA anti-beta2-gpl e lgG anti-Hsp 60/65 estão associados a risco de isquemia cerebral aguda. A associação ocorreu independentemente de outros fatores de risco. Esta resposta humoral pode conectar autoimunidade, trombofilia e aterosclerose em pacientes com isquemia cerebral.

PALAVRAS-CHAVE: anticorpos anti-beta2-gpl, anticorpos anti-Hsp 60/65, isquemia cerebral aguda.

\footnotetext{
'Laboratório de Imunorreumatologia, Pontifícia Universidade Católica do Rio Grande do Sul (PUCRS), Porto Alegre, RS, Brasil; 2INOVA Diagnostics, Inc., San Diego CF, USA; ${ }^{3}$ Serviço de Neurologia, Hospital São Lucas da PUCRS; ${ }^{4}$ Serviço de Reumatologia, Hospital do Servidor Estadual "Francisco Morato de Oliveira", São Paulo SP, Brasil. Supported in part by the Remaining Funds of the Brazilian Society of Rheumatology.
}

Received 21 February 2003, received in final form 28 April 2003. Accepted 19 May 2003.

Dr. Henrique Luiz Staub - Serviço de Reumatologia, Hospital São Lucas da PUCRS - Av. Ipiranga 6690/220 - 90610-000 Porto Alegre RS Brasil. E-mail: henriquestaub@terra.com.br 
Approximately one third of the cases of cerebral ischemia have no apparent cause ${ }^{1}$. The phospholipid cofactor beta2-glycoprotein I (beta2-gpl) and the 65 kilodalton $(\mathrm{kDa})$ heat-shock protein $(\mathrm{Hsp})$ are atherosclerotic plaque components ${ }^{2,3}$. An immunological response directed to plaque structures may be involved in the etiopathogenesis of stroke. Antiphospholipid antibodies (aPL), either anticardiolipin (aCL) antibodies or the lupus anticoagulant, have been related to the so-called antiphospholipid syndrome (APS) ${ }^{4}$. Cerebral infarctions have been observed in up to a third of cases of definite APS 5 . The overall prevalence of aCL antibodies in patients with ischemic stroke is about $10 \%{ }^{6}$. In patients under 50 years of age, this prevalence might rise to $18-46 \%{ }^{7}$.

In recent years, antibodies to beta2-gpl have been described in patients with $\mathrm{APS}^{8}$. The frequency and pathogenic role of these antibodies in patients with stroke have been a matter of discussion. Our report includes a complete profile of IgG, IgM and IgA antibeta2-gpl antibodies in patients with ischemic stroke. A cell response to heat stress has been known for the last 30 years. Currently, this response has been linked to the presence of Hsp. These highly conserved molecules, synthesized by a number of pathogens and by humans alike, are abundant in nature. Hsp are grouped into 5 families by approximate molecular weight. Some are constitutive (Hsp 70), while others (Hsp 60, Hsp 90) appear to express cell activation. A high degree of homology between human and bacterial Hsp has been observed ${ }^{9}$. A link between Hsp and autoimmunity has been postulated. High levels of antibodies to Hsp 65 and Hsp 70 (either bacterial or human) were reported in rheumatoid arthritis (RA) and systemic lupus erythematosus (SLE) ${ }^{10}$. The autoimmune response to Hsp observed in the atherosclerotic process looks intriguing. $T$ cells reactive to Hsp 60/65 were detected in the intimal layer of atherosclerotic arteries ${ }^{11}$. The role of infectious agents such as Helicobacter pylori ${ }^{12}$, as well as Escherichia coli and Chlamydia pneumoniae ${ }^{13}$, is enigmatic in atherosclerosis. Antibodies to Hsp 65/60 from patients with atherosclerosis reacted to both bacterial and human Hsp 60. Of interest, these anti-Hsp antibodies proved cytotoxic to endothelial cells ${ }^{13}$. In clinical terms, anti-Hsp antibodies have been mostly studied in patients with atherosclerotic coronary disease. Elevated levels of anti-Hsp 60 were associated with both presence and severity of coronary atherosclerosis ${ }^{14}$. Data regarding antibodies to the plaque components beta2-gpl and Hsp in cerebral ischemia are yet sparse. In this study, we set out to analyze the frequency of these antibodies in ischemic stroke. We also address the possibility that these an- tibodies are associated with risk of acute cerebral ischemia. Testing of "classical" lgG/lgM/lgA aCL antibodies was concomitantly carried out.

\section{METHOD}

This study was aproved by the PUCRS ethics commitee.

\section{Subjects}

Over a 15 month interval, we assessed aCL, anti-beta2gpl and anti-Hsp antibodies in patients with ischemic stroke and in controls enrolled in a case-control study. Only incident cases were evaluated. Subject recruitment, data collection and demographic description of the populations followed a case-control model previously reported ${ }^{15}$.

Ischemic stroke diagnosis was confirmed by the treating neurologist and was based on clinical features and changes on cranial computerized tomography (CT) or magnetic resonance imaging (MRI) ${ }^{15}$. Stroke cases were not stratified as being of atherotrombotic, cardioembolic or perfusional origin. Arbitrarily, patients with transitory ischemic attack (TIA) were not included. The neurologist was blinded to the results of any aPL or anti-Hsp assay.

Cases comprised patients at least 16 years old admitted to the Hospital in the first 7 days of onset of symptoms. Patients were not selected by sex or race. Either the patient or a proxy gave informed consent. Self-identification determined race/ethnicity. Exclusion criteria for cases were: a) cerebral haemorrhage; b) prosthetic cardiac valves or infective endocarditis; c) neoplasms (current or past); d) infection by the human immunodeficiency virus or Treponema pallidum; e) presence of known heritable causes of thrombosis such as homocistinuria or fator $\mathrm{V}$ (Leiden) mutation; f) previous diagnosis of APS or other connective tissue disorder (CTD).

The control group was concomitantly recruited from patients without stroke admitted in the Orthopaedic Infirmary due to fractures or musculoligamentar disorders. Controls were matched with cases by number (1 to 1$)$. Exclusion criteria were: a) osteonecrosis; b) cardiac abnormalities, infections, neoplasms, heritable diseases, APS or CTD as listed above for "cases".

Historical, demographic, and clinical information were obtained from chart review and interview with patients and family. Risk factors for ischemic stroke included in our clinical protocol were: 1) age, sex, race/ethnicity; 2) history of hypertension; 3) current smoking; 4) history of cardiac disease (atrial fibrillation or coronary artery disease, defined as previous myocardial infarction, angina or a coronary revascularization procedure); 5 ) history of diabetes mellitus (DM); 6) hypercholesterolemia; 7) history of ischemic stroke or $\mathrm{TIA}^{16}$.

\section{Specimens}

Serum specimens were centrifuged and frozen within 2 hours of collection and stored at $-70^{\circ} \mathrm{C}$ until the aPL enzyme-linked immunoabsorbant assays (ELISA) were performed with standardized kits. 
The $\lg \mathrm{G} / \mathrm{lgM} / \mathrm{lgA}$ aCL antibody ELISA (INOVA Quantalite cardiolipin kits, INOVA Diagnostics, Inc., San Diego, USA) were performed according to a previous description. IgG and IgM isotype results were reported as IgG phospholipid units (GPL) and IgM phospholipid units (MPL), whereby 1 unit is equal to $1 \mathrm{ug} / \mathrm{ml}$ of $\mathrm{lgG}$ or $\mathrm{lgM}$. Only samples with moderate or high levels of IgG or IgM aCL antibodies (above $20 \mathrm{GPL}$ or $20 \mathrm{MPL}$ ) were considered as positive in our study. IgA aCL antibody titers were considered positive when above 15 units $^{17}$.

The IgG, IgM and IgA anti-beta2-gpl antibodies ELISA were performed as previously described (INOVA Quantalite beta2-gpl kits, INOVA Diagnostics, Inc., San Diego, USA) ${ }^{18}$. Titers were considered positive when above 20 units for IgG and IgM anti-beta2-gpl antibodies ${ }^{18}$ and, arbitrarily, when above 25 units for IgA anti-beta2-gpl.

The IgG antibody ELISA for human Hsp 60 and for Mycobacterium bovis Hsp 65 (INOVA Diagnostics, Inc., San Diego, USA) were performed according to previous descriptions. Titers were considered positive when optical density (OD) of a known sample reached at least $0.5^{19,20}$.

\section{Data analysis}

Odds ratios (OR) with $95 \%$ confidence intervals $(95 \% \mathrm{Cl})$ were used for univariate analysis. Logistic regression with $90 \% \mathrm{Cl}$ was used for the adjustment of the effects of age, sex, race, history of hypertension, current smoking, previous cardiac disease, history of DM, hypercholesterolemia and history of ischemic stroke or TIA ${ }^{21}$. All first-order interactions between historical stroke risk factors and aPL status were examined. The Hopkins scale for $\mathrm{OR}^{22}$ was utilized, whereby an OR between 1-1.5 was considered as trivial; between 1.5-3.5 as small; between 3.5-9.0 as moderate; between 9.0-32 as strong; and above 32 as very strong. Fisher's exact test and chi-square analysis were used for comparison of categorical variables, and the Student's $t$ test was used for comparison of continuous variables; a significance level of $5 \%(P<0.05)$ was considered. All analyses used procedures of the SPSS for Windows, version 9.0, Chicago, IL.

\section{RESULTS}

There were 93 ischemic stroke patients and 93 controls included in our study. Among the 93 patients with cerebral ichemia, $70(75.3 \%)$ presented with CT changes. Regarding the topography of cerebral infarction, $81.4 \%$ of patients with abnormal cranial CT had lesions in the anterior circulation (carotid system), and $18.6 \%$ in the posterior region.

Demographic data and the risk factors profile of cases and controls are shown in Table 1. Patients with ischemic stroke were more likely to be older ( $p$ $<0.001)$. Cases and controls did not differ regarding the sex. In both groups, white ethnicity largely predominated.

History of hypertension (OR $16.8 ; 95 \% \mathrm{Cl} 8.1$ to 34.9; $\mathrm{p}<0.001)$ and history of ischemic stroke or TIA (OR 17.2; $95 \% \mathrm{Cl} 6.4$ to $43.6 ; \mathrm{p}<0.001)$ ) provided the strongest associations with acute cerebral ischemia. Previous cardiac disease (OR 6.7; $95 \% \mathrm{Cl} 3.0$ to $15.0 ; \mathrm{p}<0.001)$ and history of DM (OR 6.8; $95 \% \mathrm{Cl}$ 2.5 to $18.7 ; p<0.001$ ) yielded a moderate risk for the outcome.

Table 2 categorizes cases and controls by aCL, anti-beta2-gpl and anti-Hsp antibodies status. The following were more frequent in cases compared to

Table 1. Demographic data and risk factors profile of stroke patients and controls.

\begin{tabular}{lcccc}
\hline & $\begin{array}{c}\text { Cases } \\
(\mathrm{n}=93)\end{array}$ & $\begin{array}{c}\text { Controls } \\
(\mathrm{n}=93)\end{array}$ & $\mathrm{p}$ & OR (95\%Cl)\# \\
\hline Mean age (SD\#\#) & $62.2(12.3)$ & $47.5(18.8)$ & $<0.001^{*}$ & \\
Males & $47(50.5 \%)$ & $47(50.5 \%)$ & $0.999^{* *}$ & $1.0(0.6-1.8)$ \\
Black race & $17(18.3 \%)$ & $10(10.8 \%)$ & $0.212^{* *}$ & $1.9(0.8-4.3)$ \\
Risk factors & & & & \\
History of hypertension & $78(83.9 \%)$ & $22(23.7 \%)$ & $<0.001^{* *}$ & $16.8(8.1-34.9)$ \\
Current smoking & $41(44.1 \%)$ & $30(32.3 \%)$ & $0.131^{* *}$ & $1.6(0.9-3.0)$ \\
Previous cardiac disease & $39(41.9 \%)$ & $9(9.7 \%)$ & $<0.001 * *$ & $6.7(3.0-15.0)$ \\
History of diabetes mellitus & $26(28.0 \%)$ & $5(5.4 \%)$ & $<0.001 * *$ & $6.8(2.5-18.7)$ \\
Hypercholesterolemia & $37(39.8 \%)$ & $17(18.3 \%)$ & $0.002^{* *}$ & $3.0(1.5-5.8)$ \\
History of stroke or TIA\#\#\# & $46(49.5 \%)$ & $5(5.4 \%)$ & $<0.001 * *$ & $17.2(6.4-46.3)$ \\
\hline
\end{tabular}


Table 2. aCL, anti-beta2-gpl and anti-Hsp antibodies frequency for cases and controls.

\begin{tabular}{lccc}
\hline & $\begin{array}{c}\text { Cases } \\
(\mathrm{n}=93)\end{array}$ & $\begin{array}{c}\text { Controls } \\
(\mathrm{n}=93)\end{array}$ & $\mathrm{p}^{*}$ \\
\hline Positive IgG aCL & $1(1.1 \%)$ & $1(1.1 \%)$ & 0.999 \\
Positive IgM aCL & $5(5.4 \%)$ & $3(3.2 \%)$ & 0.721 \\
Positive IgA aCL** & 0 & 0 & - \\
Positive IgG anti-beta2-gpl & $3(3.2 \%)$ & $5(5.4 \%)$ & 0.721 \\
Positive IgM anti-beta2-gpl & $13(14 \%)$ & $10(10.8 \%)$ & 0.657 \\
Positive IgA anti-beta2-gpl & $20(21.5 \%)$ & $9(9.7 \%)$ & 0.042 \\
Positive IgG anti-Hsp 60 & $11(11.8 \%)$ & null & 0.001 \\
Positive IgG anti-Hsp 65 & $32(34.4 \%)$ & $9(9.7 \%)$ & $<0.001$ \\
Positive IgG to any Hsp & $40(43 \%)$ & $9(9.7 \%)$ & $<0.001$ \\
\hline
\end{tabular}

*Fisher's exact test; ${ }^{* *} p$ value not calculated due to null frequency in cases and controls

controls: IgA anti-beta2-gpl $(p=0.042)$, IgG antibodies to Hsp $60(p=0.001)$, IgG antibodies to Hsp 65 ( $p<0.001)$ and IgG antibodies to any Hsp (60 or 65$)(p<0.001)$.

The adjusted OR for risk factors (age, sex, race, history of hypertension, current smoking, previous cardiac disease, history of DM, hypercholesterolemia and history of ischemic stroke or TIA) are seen in Table 3.

Of significance, a positive IgA anti-beta2-gpl antibody test associated with a moderate risk of ischemic stroke $(\mathrm{OR} 4.6 ; 90 \% \mathrm{Cl} 1.5$ to $14.3: \mathrm{p}=$ 0.025). The non-adjusted OR for IgG anti-Hsp 60 antibodies after Agresti correction ${ }^{23}$ was 26.1, com- patible with an association with the outcome.The presence of IgG anti-Hsp 65 antibodies yielded a small risk of ischemic stroke (OR 3.2; $90 \% \mathrm{Cl} 1.2$ to 8.3; $p=0.044)$. A positive IgG antibody test to any Hsp (60 or 65) associated with a moderate risk of stroke (OR $4.8 ; 90 \% \mathrm{Cl} 1.9$ to $12.1 ; \mathrm{p}=0.006$ ).

Using bivariate analysis, cases and controls tested for IgA anti-beta2-gpl and IgG anti-Hsp antibodies were evaluated as the association, if any, with known risk factors for stroke.

Stroke patients with IgA anti-beta2-gpl antibodies were, on average, 6.8 years older than stroke patients with a negative assay $(p=0.028)$. The pre-

Table 3. OR for aCL, anti-beta2-gpl and anti-Hsp antibodies adjusted for risk factors.

\begin{tabular}{|c|c|c|c|}
\hline & OR\# & $90 \% \mathrm{Cl} \# \#$ & $p^{*}$ \\
\hline $\operatorname{lgG}$ aCL & 1.3 & $0.1-44.4$ & 0.901 \\
\hline $\lg M a C L$ & 1.8 & $0.3-12.0$ & 0.597 \\
\hline $\lg \mathrm{A} a C L^{* *}$ & - & -- & - \\
\hline IgG anti-beta2-gpla & 0.4 & $0.1-2.6$ & 0.406 \\
\hline IgM anti-beta2-gpl & 1.2 & $0.4-3.4$ & 0.848 \\
\hline IgA anti-beta2-gpl & 4.6 & $1.5-14.3$ & 0.025 \\
\hline Ig anti-Hsp $60^{* * *}$ & not calculated & - & - \\
\hline IgG anti-Hsp 65 & 3.2 & $1.2-8.3$ & 0.044 \\
\hline IgG to any Hsp & 4.8 & $1.9-12.1$ & 0.006 \\
\hline
\end{tabular}

\#Odds ratio adjusted for age, sex, race, history of hipertension, current smoking, previous cardiac disease, history of DM, hypercholesterolemia and history of ischemic stroke or TIA; \#\#90\%Cl: $90 \%$ confidence interval; * Fisher's exact test; ${ }^{* *}$ Logistic regression not calculated due to null frequency in cases and controls; ${ }^{* *}$ Logistic regression not calculated due to null frequency in controls. The non-adjusted OR was 26.1. Cl not calculated. 
sence of IgG anti-Hsp 60 antibodies in stroke cases was consistently associated with previous cardiopathy (OR $4.4 ; 95 \% \mathrm{Cl} 1.1$ to $17.8 ; \mathrm{p}=0.047)$. The presence of IgA anti-beta2-gpl and IgG anti-Hsp antibodies did not relate to any particular topographical location of ischemic lesions (for anterior infarction, OR 0.6 to $1.2 ; 95 \% \mathrm{Cl} 0.17$ to $4.93 ; \mathrm{p}>0.514$ ).

\section{DISCUSSION}

This case-control study of incident cases includes a complete profile of anti-beta2-gpl antibodies and testing for IgG anti-Hsp 60/65 antibodies in patients with stroke. It should be emphasized that we dealt with ischemic event as outcome. As carotid ultrasound studies were not carried out in all patients, we can not assure that all cases were of atherothrombotic stroke. Out of the 93 cases, two third had abnormal cranial CT. This might be due to the fact that a number of patients were submitted to this procedure in the first 24 hours of stroke, where cranial CT is frequently normal. The predominance of infarctions of the anterior circulation was in accordance to the literature ${ }^{24}$.

We studied an unselected population of adults with stroke. Mean age in cases differed significantly from the controls, but age, as a risk factor, was adjusted by logistic regression. History of hypertension and previous history of stroke or TIA yielded the strongest associations with stroke. Our results indicated a low frequency of IgG aCL antibodies in stroke cases. The presence of this isotype did not yield any risk of cerebral ischemia. This is in concordance with a previous report ${ }^{25}$, where $\lg \mathrm{G}$ aCL antibodies were not a risk factor for ischemic stroke. However, another group of authors had reported an association of IgG aCL positivity with cerebral infarction ${ }^{26}$.

In the largest case-control study to date (524 cases), IgG and IgM aCL antibodies were consistently associated with risk of cerebral ischemia ${ }^{27}$. Brey et al., in a recent controlled study involving 259 cases of ischemic stroke, reported that IgG aCL antibodies yielded a small risk (adjusted OR 2.2) for the outcome ${ }^{28}$.

In regard to the $\mathrm{IgM}$ aCL isotype, we found a low frequency in cases as compared to controls. Being IgM an antibody of acute response, the eventual presence of this isotype $\mathrm{aCL}$ might represent more the result than the cause of ischemic stroke. In previous controlled studies including the $\operatorname{lgM~aCL}$ isotype ${ }^{27,28}$, the OR varied from significant to trivial.
Our study also addressed the possibility that antibodies to beta2-gpl associate with risk of of ischemic stroke. Beta2-gpl, a $50 \mathrm{kDa}$ natural anticoagulant, is target for aCL antibodies ${ }^{30}$. Immunization of mice with beta2-gpl generates anti-beta2gpl antibodies, aCL antibodies and APS ${ }^{31}$. A previous report has claimed that anti-beta2-gpl antibodies are more specific than the $\mathrm{aCL}$ assay for detection of thrombosis in patients with SLE ${ }^{32}$.

The antibody response against beta2-gpl in atherosclerosis is rather intriguing. Beta2-gpl has been found in atherosclerotic plaques².

In our study, the frequency of IgG anti-beta2-gpl antibodies was smaller in cases than controls. The 0.4 adjusted OR for cerebral ischemia might suggest a protective role for this antibody. Nevertheless, the adjusted $P$ value in the Fisher test $(0.406)$ ruled out this possibility.

There are few reports on IgG anti-beta2-gpl antibodies and stroke. A case of a young adult with cerebral ischemia whose only aPL antibody was an IgG anti-beta2-gpl was recently described ${ }^{33}$. Brey et al. ${ }^{28}$ reported a non-significant frequency of IgG anti-beta2$\mathrm{gpl}$ antibodies in 259 stroke patients. A null frequency of IgG anti-beta2-gpl antibodies was described in 242 elderly patients with ischemic stroke ${ }^{34}$. These findings corroborate ours, whereby IgG anti-beta2-gpl antibodies did not associate with risk of stroke.

A positive IgA anti-beta2-gpl antibody test was detected significantly more in cases than controls. After correction for risk factors, the adjusted OR indicated that IgA anti-beta2-gpl antibodies associated consistently with risk of ischemic stroke.

This association of IgA anti-beta2-gpl antibodies with stroke bring about some controversies. Only 4 out of our 20 patients with IgA anti-beta2-gpl antibodies were aCL-positive (none with $\operatorname{IgA} \mathrm{aCL}$ ). Therefore, it is likely that $\lg A$ anti-beta2-gpl and $\lg A$ aCL comprised aPL antibodies of different specificities. The need for testing anti-beta2-gpl antibodies, particularly $\lg \mathrm{A}$, in stroke patients shall be discussed.

If stroke patients with IgA anti-beta2-gpl but not $\mathrm{aCL}$ antibodies should be managed as having APS, is also a matter of debate. Should these patients be anticoagulated? As known, the 1999 consensus for APS classification does not include antibodies to beta2-gpl ${ }^{4}$. Thus, the heterogeneity of aPL antibodies could make some clinical decisions difficult.

A possible role for infections in the appearence of IgA anti-beta2-antibodies in stroke patients re- 
mains to be clarified. Our data in bivariate analysis showed that aging could be also a trigger for $\lg \mathrm{A}$ anti-beta2-gpl antibodies in stroke patients.

The relationship of anti-Hsp antibodies with stroke was also analyzed in our study. The nonadjusted OR was compatible with a strong association of this antibody with ischemic stroke. The relationship of a positive IgG anti-Hsp 60 antibody test with previous cardiopathy in stroke patients shoud be emphasized.

Concerning the IgG anti-Hsp 65 antibody, a positive test was significantly seen in cases. After logistic regression, the 3.2 adjusted OR yielded a small, but defined, association with ischemic stroke. These data support the idea that IgG anti-Hsp 65 antibodies associated with increased risk of stroke.

As multivariate analysis could not be carried out for anti-Hsp 60 antibodies due to the null frequency in controls, we decided to evaluate the data for IgG antibodies to any Hsp (60 or 65 ). The adjusted OR indicated a consistent association of these antibodies with the ischemic outcome.

The link of Hsp with atherosclerosis is an issue of recent interest. Normocholesterolemic rabbits immunized with Hsp 65 (protein found in atherosclerotic plaques) were found to develop arteriosclerosis $^{3}$. Clinically, an association of high levels of antiHsp 65 antibodies with carotid atherosclerosis has been confirmed in elderly patients ${ }^{35}$.

There have been few studies approaching a potential link of anti-Hsp antibodies with cerebral ischemia. Antibodies to Hsp 65 and to Hsp 70 were independently associated with risk of acute ischemic stroke in a survey of 180 cases $^{36}$. Our findings on anti-Hsp 65 antibodies are concordant with this report.

Mantle et al. evaluated the frequency of IgG antiHsp 65 antibodies in 89 stroke patients. Although higher in cases than controls, the antibody titers increased with age in both groups. The authors suggested that the antibody is a marker of aging, and not of stroke ${ }^{37}$. In our survey, the association of antiHsp 65 antibodies with stroke was maintained after adjustment for age and other risk factors.

Apart from ours, there is only one report on IgG anti-Hsp 60 antibodies and stroke. Kramer et al. evaluated the prevalence of this antibody in a large survey of 292 patients with cerebral ischemia. Patients and controls did not differ in antibody frequency ${ }^{38}$. Our findings regarding anti-Hsp 60 antibodies are mostly different from this report.
From these data, IgA anti-beta2-gpl and antiHsp 60/65 antibodies appeared to associate with increased risk of ischemic stroke. The multivariate analysis showed that this association occurred independently of other risk factors. If markers of a thrombophilic and/or atherogenic state in patients with cerebral ischemia, is an issue to be further confirmed.

The understanding of the number and function of the atherosclerotic plaque components might be useful for clinical practice. Beta2-gp| ${ }^{2}$ and $\mathrm{Hsp} 65^{3}$ are found in atheromas. Nevertheless, a pathogenic role for anti-beta2-gpl and anti-Hsp antibodies in stroke have yet to be proved. Epiphenomenon or not, the occurrence of these antibodies in such patients might represent a link of autoimmunity and thrombogenesis with cerebral ischemia.

Acknowledgement - The authors wish to thank Vicki J. Nelson for the excellent technical assistance.

\section{REFERENCES}

1. Sacco RL, Ellenberg JH, Mohr, et al. Infarcts of undetermined cause: the NINCDS Stroke Databank. Ann Neurol 1989;25: 382-390.

2. George J, Harats D, Gilburd B, et al. Immunolocalization of beta2-gpI (apolipoprotein $\mathrm{H}$ ) to human atherosclerotic plaques: potential implications for lesion progression. Circulation 1999;99:2227-2230.

3. $\mathrm{Xu} \mathrm{Q}$, Dietrich $\mathrm{H}$, Steiner $\mathrm{HJ}$, et al. Induction of arteriosclerosis in normocholesterolemic rabbits by immunization with heat shock protein 65. Arterioscl Thromb 1992;12:789-799.

4. Wilson WA, Gharavi AE, Koike T, et al. International consensus statement on preliminary classification criteria for definite antiphospholipid syndrome. Arthritis Rheum1999;42:1309-1311.

5. Asherson RA, Cervera R. "Primary", "secondary" and other variants of the antiphospholipid syndrome. Lupus 1994;3:293-298.

6. Antiphospholipid Antibodies in Stroke Study (APASS) Group Anticardiolipin antibodies are an independent risk factor for first ischemic stroke. Neurology 1993;43: 2069-2073.

7. Nencini P, Baruffi MC, Abbate R, Massai G, Amaducci L, Inzitari D. Lupus anticoagulants and anticardiolipin antibodies in young adults with cerebral ischemia. Stroke 1992;23:189-193.

8. Arvieux J, Roussel B, Colomb MG. Anticorps antiphospholipids et antibeta2-gpI. Ann Biol Clin Paris 1994;52:381-385.

9. Möller G. Heat-shock proteins and the immune system. Immunol Rev 1991;121:1-220.

10. Tsoulfa G, Rook GAW, van Embden JD, et al. Raised serum IgG and IgA antibodies to mycobacterial antigens in rheumatoid arthritis. Ann Rheum Dis 1989;48:118-123.

11. Wick G, Kleindienst R, Schett G, Amberger A, Xu Q . Role of heat shock protein 65/60 in the pathogenesis of atherosclerosis. Int Arch Allergy Immunol 1995;107:130-131.

12. Birnie DH, Holme ER, McKay IC, Hood S, McColl KE, Hilllis WS Association between antibodies to heat shock protein 65 and coronary atherosclerosis. Possible mechanism of action of Helicobacter pylori and other bacterial infections in increasing cardiovascular risk. Eur Heart J 1998;19:387-394.

13. Mayr M, Metzler B, Kiechl S, et al. Endothelial cytotoxicity mediated by serum antibodies to heat shock proteins of Escherichia coli and Chlamydia pneumoniae: immune reactions to heat shock proteins as a possible link between infection and atherosclerosis. Circulation 1999;30:1560-1566

14. Zhu J, Quyyumi AA, Rott D, et al. Antibodies to human heat shock protein 60 are associated with the presence and severity of coronary artery disease: evidence for an autoimmune component of atherogenesis. Circulation 2001;103:1071-1075.

15. Tuhrim S, Golbold JH, Goldman ME, Horowitz DR, Weinberger JW Minority Risk Factors and Stroke Study: design methods and baseline characteristics. Neuroepidemiology 1997;16:224-233. 
16. Kagan A, Harris BR, Winkelstein W Jr, et al. Epidemiologic studies of coronary heart disease and stroke in Japanese men living in Japan, Hawaii and California: demographic, physical, dietary and biochemical characteristics. J Chron Dis 1974;27:345-364.

17. Gharavi AE, Harris EN, Asherson RA, Hughes GRV. Antiphospholipid antibodies: isotype distribution and phospholipid specificity. Ann Rheum Dis 1987;46:1-6.

18. Lewis S, Keil LB, Binder WL, DeBari VA. Standardized measurement of major immunoglobulin class (IgG, IgA, IgM) antibodies to beta2gpI in patients with antiphospholipid syndrome. J Clin Lab Anal 1998;12:293-297.

19. Prohaszka Z, Duba J, Horvath L, et al. Comparative study on antibodies to human and bacterial $60 \mathrm{kDa}$ heat shock proteins in a large cohort of patients with coronary heart disease and healthy subjects. Eur J Clin Invest 2001;31:285-292.

20. Hoppichler F, Lechleitner M, Traweger C, et al. Changes of serum antibodies to heat shock protein 65 in coronary heart disease and acute myocardial infarction. Atherosclerosis 1996;126:333-338.

21. Rothman KJ, Greenland S. Approaches to statistical analysis. In Rothman KJ, Greenland S (eds). Modern epidemiology. 2.Ed. Philadelphia: Lippincott-Raven; 1998:181-200.

22. Hopkins WG. A new view of statistics. On line. Available: http:// www.sportsci.org/resource/stats/index. Captured in April 11 $11^{\text {th }}, 2002$.

23. Agresti A. Categorical data analysis. New York: Wiley; 1990.

24. Caplan LR. Cerebrovascular disease (Stroke). In: Stein JH (ed). Internal medicine. 5.Ed. St. Louis: Mosby,1998:997-1007.

25. Metz LM, Edworthy S, Mydlarski R, Fritzler JM. The frequency of phospholipid antibodies in an unselected stroke population. Can J Neurol Sci 1998;25:64-69.

26. Hess DC, Krauss J, Adams R, Nicholas FT, Zhary DL, Rountree HA. Anticardiolipin antibodies: a study of frequency in TIA and stroke. Neurology 1991;41:525-528.
27. Tuhrim S, Rand JH, Wu X, et al. Elevated anticardiolipin antibody titer is a stroke risk factor in a multiethnic population independent of isotype or degree of positivity. Stroke 1999;30:1561-1565.

28. Brey RL, Abott RD, Curb JD, et al. Beta2-gpI dependent anticardiolipin antibodies and risk of ischemic stroke and myocardial infarction. The Honolulu Heart Program. Stroke 2001;32:1701-1706.

29. Carmelingo M, Casto L, Censori B, et al. Anticardiolipin antibodies in acute non-hemorraghic stroke seen within six hours within onset. Acta Neurol Scand 1995;92:69-71.

30. Kandiah DA, Krilis S. Beta2-gpI. Lupus 1994;3:207-212.

31. Gharavi AE, Sammaritano LR, Wen J, Elkon EB. Induction of antiphospholipid antibodies by immunization with beta2-gpI (apoliprotein H). J Clin Invest 1992; 90:1105-1109.

32. Cabiedes J, Cabral A, Alarcon-Segovia D. Clinical manifestation of antiphospholipid syndrome in patients with systemic lupus erythematosus associate more strongly with anti-beta2-gpI than with antiphospholipid antibodies. J Rheumatol 1995;22:1899-1906.

33. Chen WH, Liu JS. An unusual increase of blood anti-beta2-gpI antibody but not antiphospholipid antibody in cerebral ischemia: a case report. Angiology 2001;52:149-154.

34. Heinzlef O, Abuaf N, Cohen A, Amarenco P. Recurrent stroke and vascular events in elderly patients with anticardiolipin antibodies: a prospective study. J Neurol 2001;248:373-379.

35. Xu Q, Willeit J, Marosi M, et al. Association of serum antibodies to heatshock protein 65 with carotid atherosclerosis. Lancet 1993;341:255-259.

36. Gromadzka G, Zielinska J, Ryglewicz D, Fisher U, Czlonkowska A. Elevated levels of anti-heat shock protein antibodies in patients with cerebral ischemia. Cerebrovascular Dis 2001;12:235-239.

37. Mantle R, Singh B, Hachinski V. Do serum antibodies to heat-shock protein 65 relate to age or stroke? Lancet 1995;346:1715.

38. Kramer J, Harcos P, Prohaszca Z, et al. Frequencies of certain complement protein alleles and serum levels of anti-heat shock protein antibodies in cerebrovascular diseases. Stroke 2000;31:2648-2652. 